
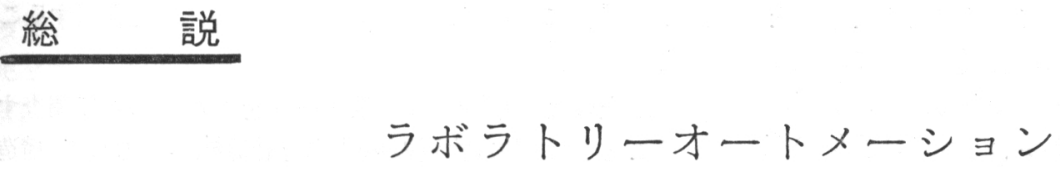

\author{
杉 谷嘉 則*・藤 原譲** \\ * 筑波大学化学系 \\ ** 筑波大学電子情報工学系 (茨城県新治郡䧌村)
}

\title{
Laboratory Automation
}

Yoshinori SUgITANI* and Yuzuru FujIwARA**

\footnotetext{
* The University of Tsukuba, Institute of Chemistry

** The University of Tsukuba, Institute of Information Sciences and Electronics (Sakura-mura, Niihari-gun, Ibaragi-ken)
}

\section{1 はじめに}

ミニコンピュータ，マイクロコンピュータの急激な発 展により,コンピュータを内蔵した計測機器やコンピュ ータシステムと一体化した各種分析機器の普及が近年, 急速化の度を加えつつある。このような状況のもとでラ ボラトリーオートメーションがクローズアップされてい るが, このラボラトリーオートメーション (以後LA と 略記）とはどういらものか，またそれを個々の研究室， 研究者のレベルで取り入れるにはどらアプローチしたら よいかといった問題につき, 実例をもって解説を試みた いと思う。LA が単なるオートメーションと区別される のは対象が実験室における研究活動といらばく然とした ものである点にあり，したがって LA に対する考え方も 人により様々であって明確な定義も確定していないとい

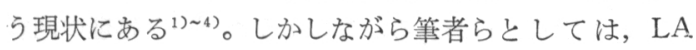
を単に実験装置における測定の自動化のみに限定しない で, 実験の前段階である調査, 計画段階から, 結果の解 析やその出力までにいたるすべての研究活動段階を含む ものと考える立場に立っている ${ }^{2)}$ 。すなち 図-1 でい えば中央の実験部分の自動化が初期における LA の考え の主な対象で，そこではコンピュータを用いたデータの

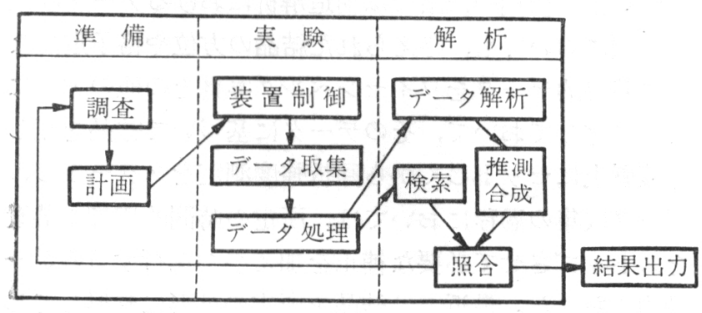

図-1 ラボラトリーオートメーションの概略22
収集と簡単なデータ処理(たとえばベースラインの補正, ピーク位置検出, ピーク面積の計算など), それに一部の 装置制御（たとえば繰り返し測定など）がプログラムに より処理される, といった程度のものであったが, 次第 に発展するにつれて, データ解析の過程までもが LA'の 対象に組み込まれてくるようになった。もちちん, なま の測定值から物理的化学的に意味のある特性值などをコ ンピュータにより数值計算で求めることは従来から行わ れていたが, それらの結果が多数収集され, 磁気テープ や磁気ドラム等にメモリーされて整理されるようになる と，それ自身がデータバンクないしデータベースとして 独立に意義のある存在となるようになり, それと解析計 算過程そのものが直結されるようになってきた。標準デ ータとの照合もこれにより容易に行うことができるよう になり, 場合によりデータの合成, 推測も多变量解析, 学習などの手法をとり入れて行うなど, 研究者の活動を 大いに助けてくれるようになった。さらに，各種文献の データベースも作成され市販されるようになり, 調査や 企画といった準備段階にも LA の思想が浸透するように なってきた。

さてこの様な広範囲の内容を含みもつ LA.を概観する にあたり，一本の筋を通して全体像をわかりやすくはあ くできるようにするため, 例として結晶構造解析のプロ セスを取り上げてみたいと思う5, 6)。この例において, LA に拉ける各部分段階から全体一の有機的な関連を, ひとつの研究活動分野の中でながめられるといら利点が ある。LA.の各部分段階 (準備段階7) 15), 実験段階 ${ }^{16)}$ 19)，解析段階20) 28) ) ごとにお污るいろいろな研究 分野 での具体化例についてはすでに数多くの解説や報告があ るので，そちらにゆずりたいと思う。結晶解析の作業 は, それ自体, 裏門的な知識と経験を要することである 
が，仕事の具体的内容はさておいて，令の目的とすると ころは単純明快であり，すなわち，物質中の原子配列の 座標を決定しょうとするだけのものであるから，専門， 非専門の別なく, 経験の有無にかかわりなく, 全体の流 れを容易に追うことができると思う。

\section{LA の全体像一一結晶構造解析との 関連において——}

\section{$2 \cdot 1$ 調査, 計画}

ある物質の単結晶が手元に得られたと仮定して，それ についての必要な情報を文献調查して求めることから始 めなければならない。構造解析が既に行われているのか いないのか, 自分の必要とする精度まで答が得られてい るか否か，そしてたとえ構造解析が行われていないにし ても, 格子定数なり, 比重その他の基礎的物性值が求め られているか否か，などを調べなければならない。最も よく利用されるデータベースとして CA.Con (Chemical Abstracts Condensates) や CASIA (Chemical Abstracts Subject Index Alert) があげられよう。いずれも構造解 析とは直接の関係はなく, 広く物理, 化学々の他の基礎 応用の研究者に利用されているもので, 前者は約 14,000 種の雑誌, 専門書, 報告等から書誌事項とキーワードを 集めたもので抄録を含まないが，年間約50万件追録され ている。後者は.ケミカルアブストラクト中の化合物及び 主題に関する索引を集めたもので，化合物に関する正確 な情報に手早く到達できる。結晶解析専用のデータベー スとしては主なところでは次のようなものが知られてい る。

CRYSDATA (NBS 米国) Crystal Data Determina= tive Table の略で, 約 24,000 の結晶の構造式, 化合物 名のファイルである。

2 DTS (米国 Joint Committee on Powder Diffraction Standards JCPDS) Diffraction Data Tele Search の略 で, 約 28,000 の粉末回析のデータがのっている。

PDB(米国 Brookhaven National Laboratory) Protein Data Bank の略で, 球状タンパク質, 䤉素の X線構造 データがのっている。

XDC (英国 Crystallographic Data Center) 1935 年 以来の有機化合物構造解析文献ファイル (XBIB) と 1960 年以来の数值データファイル (XDATA) よりなる。

これらの外に，一般の数值情報すなわち物性值やスペ クトル情報などのデータベースも多種類利用可能であ り，化学に関連する主なものだけでも約 200 種を越えて いる。研究活動はデータベースを利用すると同時にデー 夕を生産するのであるから，それぞれの研究に則した柔 軟な利用方式が必要である。データベースは通常大型計 算機を用いるが，ミニコンピュータを用いて比較的記憶 容量が小さくて済む数值データや文献データを処理した
り，場合によってはマイクロコンピュータを利用するこ ともある。

以上のような過去の文献データをさかのぼって調査す ることとは別に,物質の示性式を計算機へ入力して, 構造 や物性を推定しょうとする試みも行われている ${ }^{15)}$ 。有機 化学では元素分析值や示性式が知られていても，それに 対する分子構造や結晶構造は幾何的組み合わせの数とし てみると膨大な数となるので計算機により系統的に数え 上げて評価，選択を行うことにより，構造解析作業にお ける時間や余分な労力の節約を行うことができる ${ }^{29) \sim 32) 。 ~}$

\section{$2 \cdot 2$ データ収集, データ処理と装置制御}

構造解析の作業におけるデータ収集の主なものは回折 $\mathrm{X}$ 線の強度測定である。図-2 は, 構造解析の作業を登山 にたとえて示したもので, 左方の格子定数, 空間群と書 いてある部分から回折強度Iの部分に至る山道がこの過 程に相当する。測定しなければならない回折斑点の数は 簡単な構造の無機結晶では数百, そして複雑な有機物結 晶では数千点に及ぶ5》。今から 10 年程前の時点ではほと んどの結晶学者が, そして 20 年程前の時点ではすべの 結晶学者がこの測定をいわば手動で行っていたことを思 えば,このデータ収集過程におけるLAの偉力はまさに 絶大なものがある。この場合の手動とは写真にとられた 回折斑点の位置 ( hkl 指数) と強度を読みとることであ るが，補助的手段はあるものの結局のところは目測に頼 るものであり，忍耐と根気のいる作業であった。現在で はこの過程をX線自動回折装置(いわゆる 4 軸回折装置) が装置種による程度の差こそあれ代行してくれ，精度に おいても波高分析器からの電気出力をデジタル化して提 示してくれるわけであるから格段の差がある。またバッ クグラウンド補正のような簡単なデータ処理はデータ収 集と並行して実行されるのが普通で，そのほか結晶解析 に特有なものとしてアッテネーションファクタや LP 補 正なども同時に行われる。このようなデータ処理の内容 は, 実験の種類に忘じていろいろ異なるものが存在する が，一般的によく行われる処理としては，繰り返し積算 による $\mathrm{S} / \mathrm{N}$ の向上化, 最小自乘法の適用, 分解能向上 のためのデコンボリューション゙3), さらに FFT と逆 FFT の組み合わせによる不必要な周波数成分の除去 ${ }^{34)}$ など各種の処理がある。

LA 化の初期の段階では構造解析におけるデータ収集 の手順においても，与えられた結晶の方位や格子定数な どの基礎的データをワイセンベルグ写真その他の方法に より決定しておいて，そのデータに基づいて結晶を正し く装置上にセットしてから回折強度測定をスタートし， データ収集の過程においては, 所定の時間的周期で装置 をストップさせて必要な補正を加えつつ進行するのが一 般的であった。最近では結晶を所定の外形に整形してし っかりとセットするだけで良いものも出現するようにな 
ってきた。すなわち，装置は初めしばらくランダムな測 定を行っていくつかの強度データを収集し, その結果に 統計的処理と判断を数学的プログラムに従って実行して いくつかの主要な回折線に hkl 指数をつけ, 同時に結晶 の正しい方位を決定し，それから以後はその方位を基準 にして他のすべての回折線の指数づけと強度測定を順次 行っていくのである。

回折X線の進行する方向にシンチレーションカウンタ 一のプローブを正しく運ぶ操作は, いわ何る 4 軸ゴニオ メータ上で $2 \theta, \omega, \chi, \phi の 4 つ の$ 角度を自動的に動かし ながら次々と結晶とカウンターの相対位置を変えること により行われるわけであるが，この過程こそ，構造解析 と LA との関連におけるひとつの中心部分をなすといっ

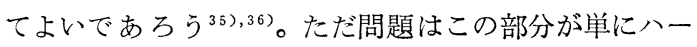
ドウェア, ソフトウェアにおける方法論的な背景の複雑 さだけでなく, 機械工学的な精度もからんでくるので, 研究者個人のレベルでこのような LA システムとしての 装置を構成することはかなり困難で, 実状としてはメ一 カーの製作による 4 軸回折装置にほぼ全面的に依存しな ければならず，その分だけ，LA の一部の側面である手 作りのニュアンスにそしくなってくる。したがって，そ の辺の不足を補う意味で, 後程, 簡単な他例をもって解 説を試みたいと考える。

\section{$2 \cdot 3$ デー夕解析}

データ収集の作業により回折X線の強度 $\mathrm{I}_{0}$ のセット (斑点の数だけの $\mathrm{I}_{0}$ ) が求まり, かつこの平方根に相当 する構造振幅 $\left|F_{0}\right|$ が求まったら実験は終了で, 次の過程 はこの $\left|\mathrm{F}_{0}\right|$ を土台にして原子座標を求めるためのデータ 解析の作業となる。構造解析を登山にたとえるなら, 胸 突き八丁かあるいは道のない岩場にさしかかったような もので, ここでの主な問題性 $\left|\mathrm{F}_{0}\right|$ のデータの組から構造 因子F（やはり斑点の数だけある）を求める，いわゆる 位相問題と呼ばれるものである。ひとたび構造因子Fが 求まってしまえば, 目的の原子座標は $\mathrm{F}$ 含む算術計算 つみで簡単に求めることができる。この位相問題の解決

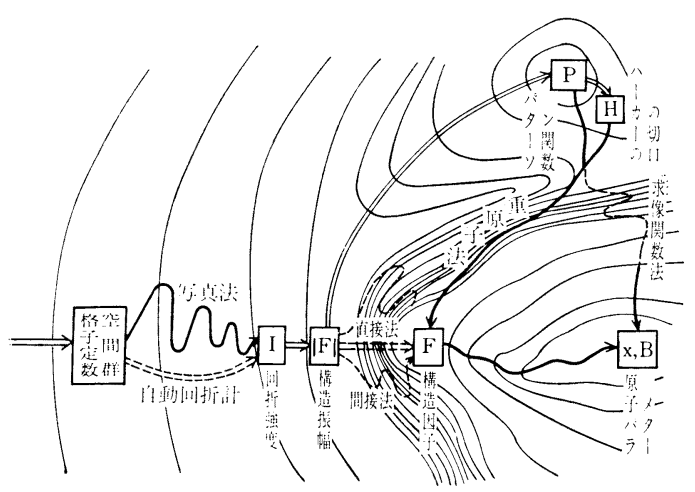

図-2 結晶解析の手順を登山にたとえる5
のために, 直接法, 間接法, パターソン関数を利用する 法などいくつかの方法があり，それに応じていろいろな 計算（データ解析）が必要となる。表-1 は構造解析に 必要な計算を 5 組に分類して示したものであるが，デー

表-1 主要な構造解析の計算 ${ }^{5)}$

\begin{tabular}{|c|c|}
\hline 計 算の種類 & 計 算 内容 の 例 \\
\hline $\begin{array}{ll}\text { 1. } & \text { データ処理 } \\
\text { 2. } & \text { 直接法 } \\
\text { 3. フーリエ合成 } \\
\text { 4. 構造因子, 最小 } 2 \text { 乗法 } \\
\text { 5. 各種関数の計算 }\end{array}$ & $\begin{array}{l}\text { 格子定数, 強度補正 } \\
\text { 不等式法, 統計法 } \\
\text { フーリエ合成, パターソン合成 } \\
\text { 結晶構造因子, 最小 } 2 \text { 乗法 } \\
\text { 原子間距離, 角度, 熱振動の解析 }\end{array}$ \\
\hline
\end{tabular}

タ解析としては $2,3,4$ が主として関係している部分であ る。この表にあるような計算や，その他いろいろな計算 がプログラム化され，かつ有機的汇結合した 1 つのシス テム化されたものとして我が国では結晶学会から出され ている UNICS (Universal Crystallographic Compu= tation Program System) が知られ, 大型計算機の設置 されている場所ではこれらがファイルされ公開されてい る。このシステムも初期の簡単なものからしだいに改 良, 拡大されてきたもので，もちろん優れたものである がこれとて決して完全なものでなく，今後も改良されて 行くべきものである。他に同種のシステムとしてたとえ ば米国 Maryland 大学で開発された X-RAY SYSTEM 1972 (An Integrated Program System for Crystal Structure Analysis) なども東大大型計算機センターにフ アイルされ公開されている。いずれにせよ，おの扔のの 研究者が各自の研究室で収集した回折強度データの出力

(テープなりカードなり)をそのままこれらのシステム の入力として適合するよらにハード及びソフトの面で整 えてやれば, データ解析の領域にまで挔大された LAの 恩恵に浴することができるわけである。

\section{$2 \cdot 4$ 結果の出力}

位相問題が片づいて構造因子が求まり, それによって 原子座標が決定されれば, 結晶構造解析の基本的な作業
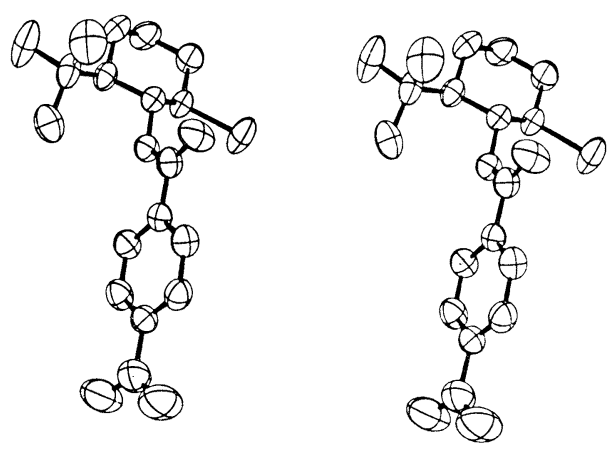

図-3 結晶解析結果の出力の例 ${ }^{37}$ trans-2-bromo-trans-6-t-butylcyclohexyl $p$-nitrobenzoate $\mathrm{C}_{17} \mathrm{H}_{22} \mathrm{NO}_{4} \mathrm{Br}$ の分子 
は終了であるが,原子座標の結果のみでなく原子間距離, 結合角のデータなども利用者にとって大変便利であり， しかもプログラムにより簡単に求められるわけであるか ら，これらの結果もあわせて出力させるのが普通であ る。またそれに先だって, 最小 2 乘法により, 得られた 原子座標值をさらに精密化することも行われるが，この 段階になって最後のだめ押しのような形で原子の熱振動 の效果を取り入れることにより精密化をさらに徹底化す る試みが行われる。図-3 の球ないし棈円球はその結果 を表したもので，おのおのの原子が熱振動している範囲 を示したものである。この図において右側の部分を右の 目で左側の部分を左の目で見るようにすると原子配列の 有様が立体的に浮かびあがって見える。視角の差を利用 したものであるが，複雑な結晶で原子相互の位置関係が 平面に投影しただけのものからではつかみ難いような場 合に，この立体図によって原子の立体配置が実感的にと らえられる。このような作罒もプログラムにより容易に 行わ礼るので, 非常に良く利用されている。

\section{$3 \mathrm{LA}$ ヘのアプローチの手近な例—— マイクロコンピュータを利用した けい光寿命測定系}

結晶解析という作業を例にとって LA というものを概 観してきたわけであるが，結晶学者たちが過去に営々と して築きあげてきた結晶解析システムのほさんど全行程 が今や一台の最新式自動回折装置で置きかえられよう上 しており，その意味においてこの例はLAのもつ手作り のニュアンスを伝えるにはやや不満が残る。そこで少々 趣きが異なるが，最近管者らが試みた，マイクロコンビ ユータを使ったけい光寿命測定装置系の製作例定紹介す ることにより上記の点の補いとし，かつLAの導入の手 近な参考例としたい。

けい光寿命の測定装置は, それ自体が独立の装置とし て市販されているが，特に有機反応などに扔けるナノ秒 程度のけい光寿命をシングルフォトンカウンティング法 によって測定するものは数百万円から一千万円にもなる

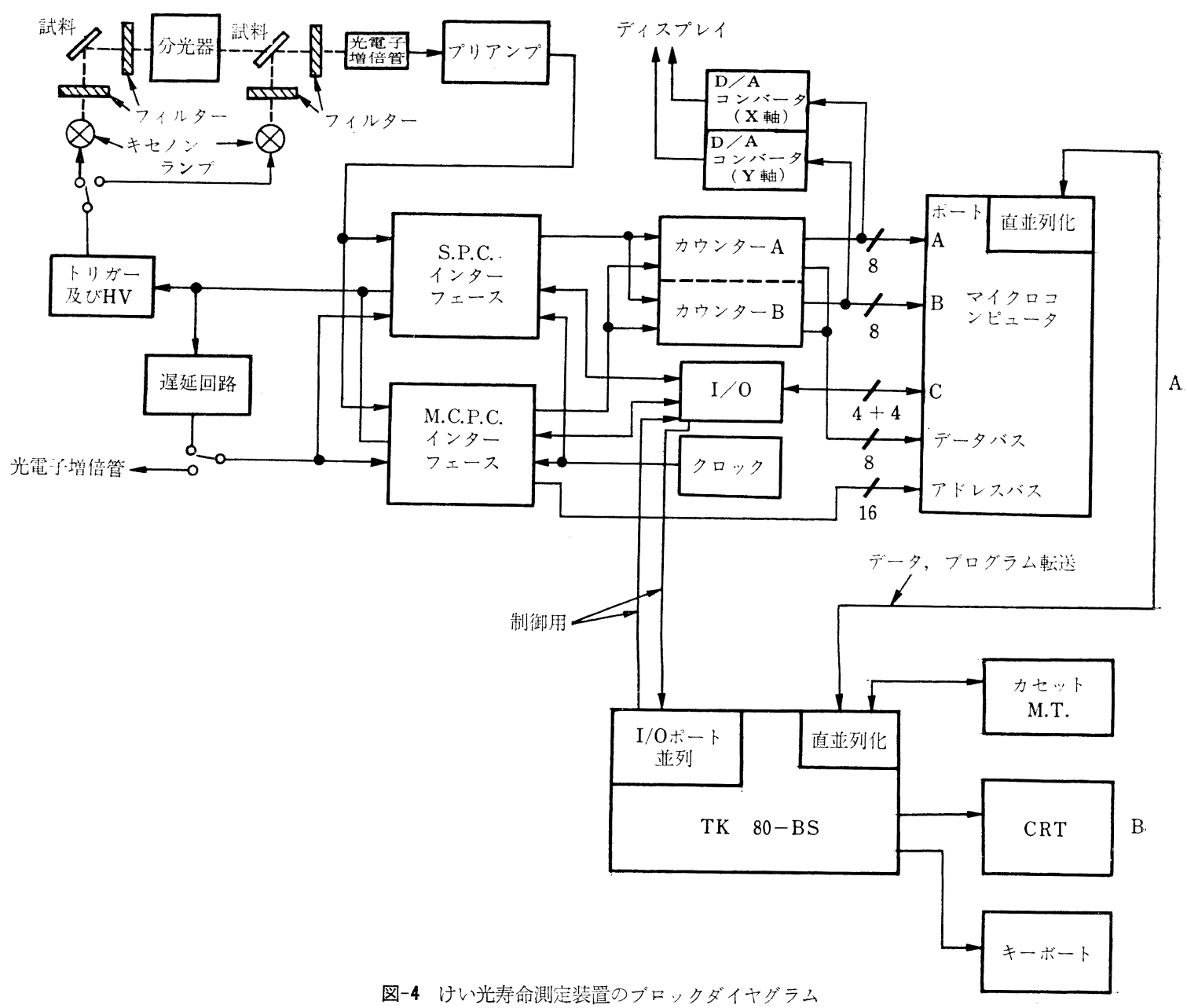


高価なものである。一方，無機化合物特に固体の試料の けい光寿命は一般に有機化合物のそれに比べてはるかに 長く, マイクロ秒からミリ秒の範囲にかなりのものが入 ってくる。しかしながら, この程度の寿命をおもな測定 筑围とする装置は意外なことにあまり市販品がなく，し たがってボックスカー積分器やデジタルメモリ一装置を 用いて自作することになるのであるが，これまた高価で あったり測定に時間を要したりで思うようになりにく い。そこで, マイクロコンピュータを利用してこの問題 をなんとか解決できないものかということで，その実現 化に取りくんだ。普通のけい光スペクトルの測定装置は 手元にあるので, 問題はこの検出器 (光電子増倍管) の 先にマイクロコンピュータと必要なインターフェースを とりつけて, けい光出力の時間変化を逐次読みとり, 次 次にメモリーへ送りこむ作業をさせてやればよいわけで ある。

その結果でき上がったものが 図-4 のブロックダイア グラムに示すものである (上側 Aの部分)。マイクロコ ンピュータとしては良く知られた NEC 製の TK-80を 用いた。今になって，もっと上クラスのマイクロコンピ ュータを使っておいた方が必要なプログラムも BASIC を用いてより楽化組めたであろうし，また抆張性もあっ て便利だったろらなどと考えているが，当初において は, 安価で気楽なマイクロコンピュータなればこそ, 気 楽にかような仕事にとりかかれたといら側面も㐫ったこ とは見逃せない。けい光測定のモードは二つあり，シン グルフォトンカウンティング法とマルチチャンネルフォ トンカウンティング法である。マイクロコンピュータは 動作が遅く, せいぜい数 $10 \mathrm{KHz}$ までしか使えないの で, 高速を必要とする部分は TTL ロジックで組み, デ 一タの取り込みを速くするようにした。まず, シングル フォトンカウンティング法では, 図の中のカウンターA は時計として, カウンターBはフォトンの計数用として 働く。この測定方法に㧍ける収集データは, 光励起の瞬 間から発光による第 1 個目のフォトンが到着するまでの 時間間隔だけなので, データのメモリーへの取り込みは 速くなくてもかまわない。そこで，取り込みはTK-80の I/O ポートを利用して行い, カウンターBの内容が 1 で あるときのみ, カウンターAの内容をメモリ一の番地と して，そこに1を加算するようになっている。このよう な測定を多数回繰り返して行った上で, 加算された結果 をメモリ一番地を横軸にとってはき出させれば，それが けい光の減衰曲線を表すことになる。次に, マルチチャ ンネルフォトンカウンティング法では, 計数速度もデー タのとり込みも速くする必要があるので, カウンター A，B を交互に計数用に用い，一方が計数している間に 他方の内容を DMA 転送 (Direct Memory Access, コ ンピュータの中央制御部を経ないで，直接にメモリー部
からメモリー部ヘデータを転送して処理時間を節約する 手法)でメモリーへ送りこむようにしてある。これによ り, 計数速度最大 $30 \mathrm{MHz}$, 取り込み速度最大 $2 \mathrm{MHz}$ と することができた。このようにしてデータの取り込み操 作を必要回数だけ繰り返し積算して, その結果をXYレ コーダー上に出力する。また, 途中のデータ収集の状況 は，つ政にXYオシ口の上に表示されるようになってい るのでこれをモニターすることができる。

以上が当初の目的のけい光寿命測定装置としての概略 であるが，これだけの作業を TK-80 一台で扱うという のはいかにもきつく，大きな制約が伴う。すなわち使元 るメモリーがごく限られているので（ボード上 $1 \mathrm{~K}$ バイ ト）他のいろいろなプログラムを入れることもできず， またこのままでは BASIC を使用することができない。 そこで，次なる段階として，同じく NEC 製の TK-80 BS をこれに連結し，機能分担させて余裕をもたせ，LA 化を今一歩進めたものが 図-4 (AとB合わせた全体) である。ここでは，TK-80 测定そのものとデータの 蓄積 (各試料ごとの) を行い, TK-80 BS では補正や比 較などのデー夕処理をもっぱら行う。TK-80と TK-80 BS における作業の流れは 図-5 のようになっている。 両者の間では, データ.の転送だけでなくプログラムその ものも転送することができる。結線はすべて同軸ケーブ

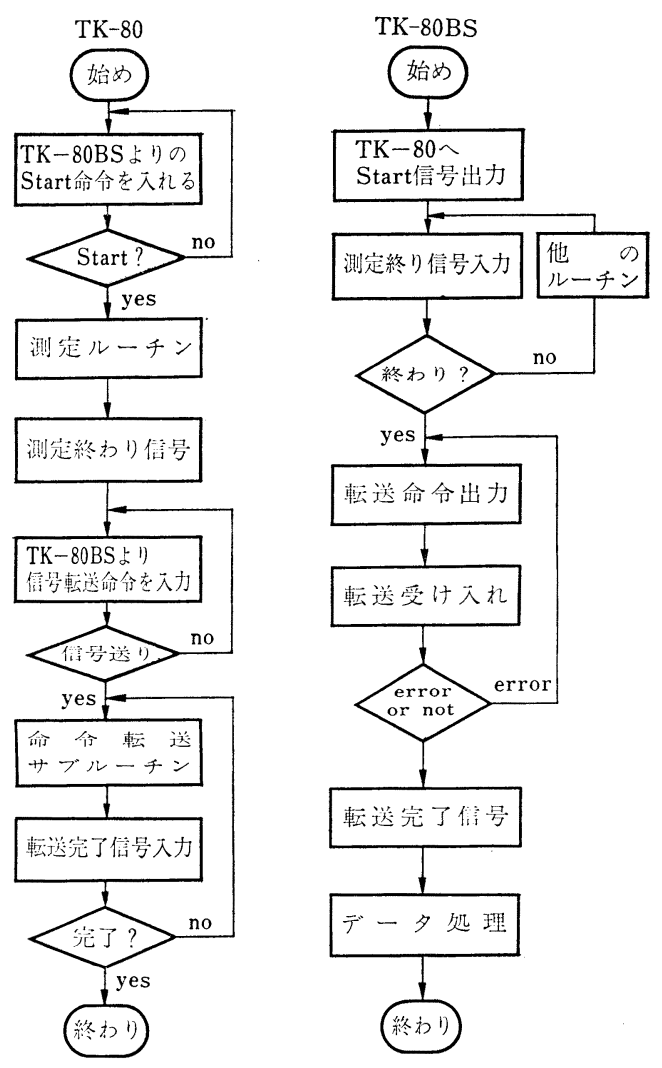

図-5 TK-80 と TK-80 BS に予ける仕事の流れ図 
ルを用いているが，データ転送の際の直列化，並列化は プログラマブル・コミュニケーション・インターフェー ス $\mu \mathrm{PD} 8251$ を用いて高速転送ができるようにしてあ る。このようにすれば，BASIC によるいくつかの新し いプログラムを入れることもできるので，このシステム を容易に寿命測定装置以外の目的に転用することも可能 である。たとえば, マルチチャンネルフォトンカウンテ イング法で使用する場合, 分光器をデジタル駆動式に変 えてやれば時間分割スペクトルを一度に測定してしまう ことが可能となる。

以上は, 実験室における LA 化のほんの一例を示し たものに過ぎないが, それぞれの研究室の活動内容に応 じていろいろな LA 導入の可能性があるものと考えられ る。あらゆる分野にマイクロコンピュータが爆発的勢、 で浸透しつつある昨今, 意欲と工夫しだいでいかように もこれらを取り込んで研究活動を高めて行くことが可能 と思われる。

本稿の執筆汇関し, 筑波大学物質工学系・大政正明博士及び 同化学系・加藤 健次氏御教示と御協力を賜わった。ここに深 謝する。

（昭和 54 年 2 月 14 日受理）

\section{文献}

1) H. Cole et al., 計測と制御, 14, 4 (1975)

2) 藤原 譲, 石油学会誌, 19, 568 (1976)

3）石田順一， ぶえせき，5, 289 (1976)

4）鉒 三夫，情報処理，19，165 (1978)

5) 桜井敏雄「X線結晶解析」第 4 版. 裳華房 (1972)

6) G.H. Stout, L.H. Jensen, "X-ray Structure De= termination”, McMillan (1972)

7) C.S. Rann, Anal. Chem., 44, 1669 (1972)

8) K. Tanabe, S. Saeki, Anal. Chem., 47, 118 (1975)

9) S. R. Heller, Anal. Chem., 44, 1951 (1952)

10) S. R. Heller, D. A. Koniver, H. M. Fales, G.W.A Milne, Anal. Chem., 46, 974 (1974)

11) H. Rotter, K. Varmuza, Org. Mass Spectrom., 10, 874 (1975)
12) Y. Fujiwara et al., Macromolecules, 280 (1970)

13）米田幸夫, 東大大型計算機 センターニュース, 8, 21 (1976)

14) E. J. Corey et al., J. Am. Chem. Soc., 94, 421 (1972)

15）米田幸夫「ケモグラム」丸羓 (1972)

16) R.W. Hendler et al., Anal. Chem., 49, 1908 (1977)

17) W.S. Woodward et al., Analyst, 99, 838 (1974)

18) R. Kaiser, J. Mag. Res., 3, 28 (1970)

19) C. N. Reilley, W.S. Woodward, T.H. Ridgway "Information Chemistry", Tokyo Univ. Press (1974)

20）銭谷福男, 南 茂夫, 応用物理, 43, 138 (1974)

21） R. N. Jones et al., Spectrochim. Acta A, 23 A, 925 941 (1967)

22) J.W. Cooly, J.W. Tuckey, Math. Computation, 19, 297 (1965)

23）藤原 譲ら, 日本自動制御協会ミニコン研究分科会資料, A-75-02-1 (1975)

24）浜口隆信, 青木 啓, 分析機器, 11, 493 (1973)

25）横山友, 池田重良, 分析化学, 20, 1497 (1971)

26) H. Kojima, S. Fujiwara, Bull. Chem. Soc. Jpn., 44, 2158 (1971)

27) S. Sasaki et al., Anal. Chem., 40, 2220 (1968)

28) C. L. Wilkins, T. L. Isenhour, Anal. Chem., 47, 1849 (1975)

29) E. J. Corey et al., J. Am. Chem. Soc., 94, 421 (1972)

30) E. J. Corey et al., J. Am. Chem. Soc., 96, 7724 (1974)

31) E. G. Smith, "The Wisswesser Line Formula Chemical Notation”, McGraw Hill(1968); 平山健三, 估ヶ木慎一訳「WLN-化学構造式の線型表記法」南江堂

32) G. M. Dyson, "A New Notation and Enumeration System for Organic Compounds", Longmans (1949)

33) R. N. Jones et al., Spectrochim. Acta A, 23 A, 925, 941 (1967)

34) S. Cohn et al., Proc. IEEE, 63, 1460 (1975)

35) U.W. Arndt, B.T.M. Willis, "Crystal Diffracto= metry”, Cambridge Univ. Press (1966)

36) W. R. Busing, H. A. Levy, Acta Cryst., 22, 457 (1967)

37) F. Brisse et al., Acta Cryst., B 32, 2128 (1976) 